\title{
Analisis Yuridis Qanun Jinayat dalam Strukturisasi Hukum Pidana Nasional
}

\author{
Erfin Dermawan Surbakti ${ }^{1}$ dan Endang Agoestian ${ }^{2}$ \\ ${ }^{1}$ Fakultas Syari'ah IAIN Zawiyah Cot Kala Langsa Aceh. E-mail: erfindermawan07@gmail.com \\ ${ }^{2}$ Fakultas Syariah, IAIN Jember.E-mail: endangagt2000@gmail.com
}

\begin{tabular}{|c|c|}
\hline Article & Abstract \\
\hline $\begin{array}{l}\text { How to cite: } \\
\text { Erfin Dermawan Surbakti } \\
\text { dan Endang Agoestian, } \\
\text { 'Analisis Yuridis Qanun } \\
\text { Jinayat dalam } \\
\text { Strukturisasi Hukum } \\
\text { Pidana Nasional' (2020) } \\
\text { Vol. } 1 \text { No. } 2 \\
\text { Rechtenstudent Journal } \\
\text { Fakultas Syariah IAIN } \\
\text { Jember. }\end{array}$ & $\begin{array}{l}\text { The Nanggroe Aceh Darussalam is a city that is thick with Islamic law. It has a } \\
\text { population of around 5,281,891 people, the majority of whom are Muslim. Particular } \\
\text { regions that have special autonomy. Evidenced by the existence of Law No.4 of } 1999 \\
\text { regarding the implementation of Special Autonomy for Aceh province. As regulated } \\
\text { in } 1999 \text { to 2004, it has allowed local governments to issue (PERDA) regional } \\
\text { regulations. The PERDA launched by the Aceh government is the Qanun Jinayah, } \\
\text { but by issuing regional regulations, it must not conflict with existing laws or higher } \\
\text { laws. The existence of this study aims to analyze the Qanun Jinayah in the } \\
\text { structuring of criminal law. To know the presence, implementation, and reflection of } \\
\text { the Qanun Jinayah. The method used is using a qualitative descriptive analysis } \\
\text { approach with data collection techniques by triangulation. The results of this study } \\
\text { confirm that the existence of Qanun Jinayah is recognized as a national parent. There } \\
\text { is no conflict between the contents of the Qanun Jinayah and the National Criminal } \\
\text { Law. The implementation carried out can provide output that Aceh has a new law. } \\
\text { However, the existence of Qanun Jinayah cannot be separated from the reflection of } \\
\text { society, which leads to a sociological, philosophical, and juridical foundation. } \\
\text { Keywords: Qanun Jinayah, structuring, national criminal law. }\end{array}$ \\
\hline $\begin{array}{l}\text { ISSN: } \\
\text { 2723-0406 (media cetak) }\end{array}$ & $\begin{array}{l}\text { Abstrak } \\
\text { Nanggroe Aceh Darussalam merupakan kota yang kental akan syariat Islam. } \\
\text { memiliki penduduk sekitar } 5.281 .891 \text { jiwa yang mayoritas memeluk Agama Islam. } \\
\text { Daerah istimewa yang memiliki otonomi khusus Dibuktikan dengan adanya } \\
\text { Undang-Undang No.4 tahun } 1999 \text { terkait penyelenggaraan otonomi Khusus provinsi } \\
\text { Aceh. Sebagaimana yang telah diatur pada tahun } 1999 \text { sampai } 2004 \text { telah } \\
\text { mengizinkan pemerintah daerah untuk mengeluarkan (PERDA) peraturan daerah. } \\
\text { PERDA yang diluncurkan oleh pemerintah Aceh ialah Qanun Jinayah namun } \\
\text { dengan mengeluarkan peraturan daerah tidak boleh bertentangan dengan Undang- } \\
\text { Undang yang telah ada atau Undang-Undang yang lebih tinggi. Dengan adanya } \\
\text { Penelitian ini bertujuan untuk menganalisis Qanun Jinayah dalam strukturisasi } \\
\text { hukum pidana. Guna untuk mengetahui eksistensi, implementasi serta refleksi } \\
\text { terhadap Qanun jinayah. Metode yang digunakan menggunakan pendekatan secara } \\
\text { analisis deskriptif kualitatif dengan teknik pengumpulan data secara triangulasi. } \\
\text { Hasil penelitian tersebut menegaskan bahwa eksistensi Qanun Jinayah diakui } \\
\text { keberadaannya secara induk Nasional. Tidak adanya pertentangan antara isi dari } \\
\text { Qanun Jinayah dengan Hukum Pidana Nasional. Penerapan yang dilaksanakan } \\
\text { mampu memberikan output bahwa Aceh mempunyai hukum yang baru. Namun } \\
\text { adanya Qanun Jinayah tidak terlepas dari adanya refleksi masyarakat. Yang } \\
\text { bermuara pada landasan sosiologis, filosofis, dan yuridis. } \\
\text { Kata Kunci: Oanun Iinayah, strukturisasi, hukum pidana Nasional. }\end{array}$ \\
\hline
\end{tabular}




\section{Pendahuluan}

Adagium yang menyatakan bahwa "di mana ada masyarakat di dalamnya pasti ada hukum" ${ }^{\prime 1}$ artinya hukum berada di tengah-tengah masyarakat hukum meliputi hukum adat, kebiasaan, hukum yang dibuat oleh penguasa (Undang-Undang) serta hukum agama. Salah satu adanya hukum agama ialah Qanun Jinayat. Qanun Jinayah merupakan suatu Peraturan Daerah yang ada di Kota Aceh. Kota Aceh biasa dijuluki sebagai kota serambi mekah. Memiliki penduduk sekitar 5.281.891 jiwa ialah penduduk yang agamis. Agama Islam menjadi agama yang banyak dipeluk oleh masyarakat Aceh. Kota Aceh masih berada di naungan Indonesia dan dibalut berdasarkan sistem pemerintahan Negara Kesatuan Republik Indonesia. ${ }^{2}$

Qanun Jinayat Aceh Lahir atas dasar aspirasi sosiologi masyarakat. Landasan yang jelas bahwa terdapat unsur landasan filosofis, landasan sosiologis dan landasan yuridis hingga landasan historis.

Pandangan filosofis yakni berakarnya hukum Islam dalam kehidupan manusia. AlQur'an dan Sunnah menjadi pedoman dalam menentukan hukuman untuk kesalahan tertentu yang dapat mengharuskan adanya hukuman di antaranya, berzina, menuduh orang berzina tanpa bukti, mencuri, mabuk, mengacau, memberontak dan sebagainya. Adanya Qanun yang berlandaskan Pidana Islam guna untuk menjamin kemaslahatan umat dan ketenteraman masyarakat umum. Hukuman tersebut berpegang pada rasa keadilan dan untuk memberikan efek jera dengan efektivitas yang diinginkan. ${ }^{3}$

Hukum Allah telah diterapkan di negara-negara yang menerapkan secara konsisten dan membuktikan bahwa efektif dan berhasil secara nyata baik dari segi mewujudkan keamanan, ketertiban, dan kesejahteraan. ${ }^{4}$

Indonesia dalam masa yang ambigu, ringan dalam memberikan hukuman pada pelaku tindak kejahatan, maka kejahatan semakin meningkat, pelanggaran norma semakin akut dengan berbagai modus operandi yang bermacam-macam. Meningkatnya kriminalitas serta pelanggaran norma-norma hukum merupakan indikasi bahwa hukum tidak mampu memberikan efek jera kepada masyarakat. Hal yang paling dominan ialah pelaksanaan hukum, adanya ketidakadilan hukum bukanlah sesuatu yang aneh. Maka dari itu hak-hak otonomi daerah untuk meminimalisir tingkat kriminalitas serta meminimalisir pelanggaran norma dengan diberlakukan Qanun Jinayah di Kota Aceh.

Hukuman atau pidana atas perbuatan yang melanggar tercantum pada Al-Qur'an, AsSunnah, atau tertera pada Undang-Undang Pidana. Suatu asas yang disebut Nullum Crimen Sine Lege dalam Islam disebut la hukma qabla wurudinnash dalam Kitab Undang-Undang pidana telah tercantum pada pasal 1 ayat (1) KUHP. Perlu diketahui bahwa pidana dan hukuman memiliki sisi perbedaan. Letak perbedaannya apabila pidana telah tercantum pada nash-nash yang legal dan formal atau terdapat pada ketentuan-ketentuan Undang-Undang sedangkan hukuman cakupan pengertiannya sangat luas yang semuanya didasari oleh

\footnotetext{
1 Zaeni Asyhadie, Arief Rahman, Ilmu pengantar Hukum, (Jakarta: Rajawali Pers, 2016), 1.

2 Endang Agoestian, Efektivitas Qanun Jinayah Dalam Strukturisasi Hukum Pidana Nasional, (web fakultas syariah, 2020), http://fsyariah.iain-jember.ac.id/berita/detail/efektivitas-qanun-jinayah-dalam-strukturisasi-hukumpidana-Nasional- dikunjungi pada tanggal 16-08-2020

${ }^{3}$ Ishaq, Hukum Pidana, (Depok: Rajawali Pers, 2020), 52.

${ }^{4}$ Ibid., 3.
} 
kesopanan, kesusilaan, kepatutan serta kebiasaan. Namun pidana dan Hukuman juga memiliki persamaan yaitu berdasarkan tata nilai (value) baik dengan tidak baik, perintah dengan larangan. ${ }^{5}$

Pemberlakuan Qanun Jinayah pada hakikatnya juga merupakan unsur formal dalam hukum pidana Islam dan tidak jauh berbeda dengan unsur formal hukum pidana Nasional yang mana menjelaskan keberlakuan hukum dan mampu menegaskan sanksi hukum.

\section{Rumusan Masalah}

Adapun permasalahan yang diangkat menjadi pokok masalah sebagai berikut :

1. Bagaimana Eksistensi Qanun Jinayat dalam Strukturisasi Hukum Pidana Nasional?

2. Bagaimana Implementasi Qanun Jinayat Aceh Nomor 6 Tahun 2014 dalam Perspektif Hukum Pidana Nasional?

3. Bagaimana Refleksi Masyarakat Terhadap Penerapan Qanun Jinayat?

\section{Metode Penelitian}

Metode penelitian adalah suatu cara yang digunakan dalam mengumpulkan data penelitian dan dibandingkan dengan standar ukuran yang telah ditentukan. ${ }^{6}$ penelitian ini menggunakan teknik atau metode penelitian meliputi data dan sumber data. Metode penelitian merupakan suatu kegiatan keilmuan untuk memecahkan masalah atau dengan cara mengembangkan ilmu pengetahuan dengan menggunakan metode-metode secara ilmiah.7 Secara harfiah metode merupakan penyelidikan secara berlangsung terhadap suatu rencana tertentu. Guna untuk mencapai tujuan dan tidak bekerja secara acak serta langkah-langkah yang jelas dan ada pembatasan-pembatasan tertentu. ${ }^{8}$ Dalam metode penelitian hukum menggunakan bahasa hukum yang dapat dipahami oleh para akademisi serta para ahli dan segenap pengemban hukum.

Penelitian ini bermula pada rasa ingin tahu (niew-gierigheid) untuk menemukan suatu jawaban dalam suatu isu-isu aktual yang dihadapi. ${ }^{9}$ Terutama dalam isu hukum untuk memecahkan masalah hukum dan untuk menjawab semua persoalan hukum terkait dengan eksistensi, implementasi serta refleksi.

Adapun metode yang digunakan peneliti dalam penelitian ini ialah sebagai berikut:

Pendekatan konsep (conceptual Approach) pendekatan ini guna untuk mengetahui konsep-konsep tentang Qanun Jinayat dalam strukturisasi hukum pidana Nasional. Pendekatan perbandingan (Comparative Approach) pendekatan ini sebagai bahan perbandingan mengenai efektivitas penerapan Qanun Jinayat terhadap kasus-kasus pelanggaran norma-norma hukum, hal tersebut dikomparasikan antara kajian yuridis undang-undang hukum pidana Nasional dan Qanun Jinayat.

Penelitian dengan judul "Analisis Yuridis Qanun Jinayat Dalam Strukturisasi Hukum Pidana Nasional" merupakan penelitian hukum secara normatif dengan menggunakan pendekatan Undang-Undang (Statute Approach) yaitu dengan menelaah semua UndangUndang serta regulasi yang berkaitan dengan problematika hukum ataupun isu hukum yang

\footnotetext{
${ }^{5}$ Ibid., 85.

${ }^{6}$ Arikunto Suharsimi, Metodoloogi Penelitian, (Jakarta: PT Rineka Cipta, 2002), 126.

${ }^{7}$ Jonaedi Efendi dan Johny Ibrahim, Metode Penelitian Hukum Normatif dan Empiris,(Prenadamedia Group,2016), 3.

${ }^{8}$ Ibid., 4 .

${ }^{9}$ Ibid., 123.
} 
sedang dihadapi. ${ }^{10}$ Berdasarkan pendekatan ini guna untuk membuka kesempatan dalam menelaah dan mempelajari konsistensi antara Undang-Undang Nasional dengan UndangUndang Peraturan Daerah serta regulasi dengan Undang-Undang Dasar. Selain itu penelitian ini menggunakan penelitian secara sosiologis untuk mengetahui kondisi sosial serta refleksi masyarakat dengan berlakunya penerapan Qanun Jinayat yang digadangkan oleh pemerintah daerah. Selain itu, penelitian ini menggunakan Penelitian Pustaka (library research) yakni bahan sekunder berupa jurnal, buku, peraturan perundang-undangan serta artikel resmi. Penelitian Studi Kasus (Case Study) untuk memperoleh interpretasi dan gambaran terkait gejala fenomena yang terjadi. Dari keseluruhan data maka peneliti menganalisis dan menelaah dengan cara mengumpulkan data secara Komprehensif. Selanjutnya ialah analisis data yang merupakan suatu proses untuk mengatur secara sistematis dan mengkoordinasikannya kendala suatu bentuk, pola, kategori serta satuan dasar. ${ }^{11}$ Dapat disimpulkan bahwa penelitian ini menggunakan metode analisis deskriptif kualitatif. Teknik pengumpulan data secara triangulasi (gabungan), data yang dihasilkan bersifat deskriptif dan analisis data dilakukan secara induktif. Teknik yang digunakan peneliti dalam menguraikan permasalahan dan problem solving ialah teknis analisis deskriptif dengan menghubungkan atau menggabungkan data yang telah diperoleh dengan kajian teori sehingga dapat memberikan interpretasi yang jelas untuk menjawab suatu permasalahan yang diteliti. Kemudian, menggunakan teknik komparatif yaitu dengan membandingkan terhadap argumen-argumen yang lain. Baik berupa Undang-Undang Nasional dengan UndangUndang PERDA. Selanjutnya ialah melakukan evaluasi serta memberikan argumentasi sesuai dengan hasil analisis.

\section{Hasil dan Pembahasan}

\section{Eksistensi Qanun Jinayat dalam Strukturisasi Hukum Pidana Nasional}

Eksistensi Qanun Jinayat berangkat dari teori sistem hukum, sistem Hukum menurut Sudikno merupakan sistem yang utuh dari tatanan-tatanan yang terdiri dari berbagai bagian dan unsur yang satu sama lain saling berkaitan secara erat. Tokoh Lawrence Meir Friedman seorang ahli sosiologi hukum yang menempuh study di Standford University, membagi unsur-unsur hukum dalam 3 jenis di antaranya, Substansi Hukum (legal substance) yang artinya isi atau substansi yang ada dalam peraturan perundang-undangan. Substansi mencakup aturan hukum, baik hukum formil maupun materiil, baik tertulis maupun tidak tertulis hal ini berdasarkan bentuk hukum. Kemudian, Struktur Hukum (legal Structure) yaitu mencakup tingkatan hukum, peradilan, pelaksana hukum, serta badan/lembaga (pranata-pranata) hukum dan pembuat hukum. Selanjutnya ialah Kultur Hukum (legal cultur) dapat diartikan sebagai budaya hukum yang mencakup kebiasaan, opini masyarakat, dan pelaksana hukum atau penegak hukum, tata cara bertindak dan berpikir. Budaya hukum merupakan suatu cerminan dari sikap dan perilaku terhadap hukum. ${ }^{12}$

Dari tiga teori sistem hukum yang dikemukakan oleh Lawrence Meir Friedman maka dapat ditarik bahwa Qanun Jinayat terdeteksi pada budaya hukum (Legal Culture). Eksistensi dari Qanun Jinayah jelas berdasarkan landasan filosofis, sosiologis dan landasan yuridis serta

\footnotetext{
${ }^{10}$ Peter Mahmud Marzuki, Penelitian Hukum, (Jakarta: Pt Kharisma Putra Utama, 20160, 133.

${ }^{11}$ Lexy J. Moeleong, Metodologi Penelitian Kualitatif (Bandung: Remaja Rodakarya, 2010), Hlm 161.

${ }^{12}$ Zaeni Asyhadie, Arief Rahman, Ilmu Pengantar Hukum, (Jakarta: Rajawali Pers, 2016) Hlm 155-156
} 
landasan historis. Dari adanya 4 (empat) landasan ialah menjadi faktor hadirnya Qanun Jinayah Aceh.

Namun semua bermuara pada aspirasi landasan sosiologis, penduduk Aceh menjadi penduduk yang agamis, agama Islam menjadi agama mayoritas yang banyak dipeluk oleh penduduk Aceh. Landasan sosiologis merupakan faktor dengan keadaan-keadaan ekonomi, pandangan agama, serta psikologis masyarakat yang berkaitan dengan sejarah hukum, agama, ekonomi dan Ilmu filsafat. ${ }^{13}$ Menurut Lawrence Meir Friedman menyatakan bahwa tidak ada sistem hukum di negara maju yang formal dan informal. Keduanya saling berkaitan dan menyatu. Hukum dari pemerintah yang formal berstruktur, berpola dan bersangga pada bahasa yang telah tertulis terhadap lembaga dan proses yang teratur. Hukum yang jauh dari kata formal tetapi dalam perundang-undangannya baik resmi maupun tidak resmi ialah gabungan dari keduanya tersebut. ${ }^{14}$

Namun eksistensi dengan adanya Qanun Jinayah ialah terletak pada sisi budaya, salah satu dari teori Friedman yakni budaya hukum (Legal Cultural) yang mana dapat ditarik dalam pembentukan hukum. Pembentukan hukum tak terlepas dari Peraturan PerundangUndangan. Berdasarkan bentuknya hukum terdiri dari hukum tertulis, hukum tidak tertulis dan hukum peradilan (judge made law)

a. Hukum tertulis yang dikodifikasi, hukum yang susunannya lengkap, sistematis, terstruktur dan dibukukan. Peninggalan pemerintahan pada masa Hindia-Belanda yang dikodifikasi ialah KUH perdata, KUH Pidana, KUH Dagang sedangkan di negara Indonesia yang sudah dikodifikasi ialah Hukum Acara Pidana. Hukum tertulis bersifat statis dan tidak mengikuti arus perkembangan serta perubahan masyarakat. Dan Hukum tertulis mampu menjamin kepastian hukum, Hukum tertulis dalam pemberlakuannya dikeluarkan oleh badan resmi pemerintahan dan pembentukannya sesuai prosedur.

b. Hukum tidak tertulis merupakan hukum kebiasaan, hukum yang diyakini oleh masyarakat atau disebut living law yang dapat dipatuhi sifatnya informal tetapi lahir, tumbuh dan berkembang di dalam masyarakat tersebut. Hukum tidak tertulis memiliki sifat yang luwes dan dapat mengikuti perkembangan masyarakat, serta tidak mampu menjamin kepastian hukum tentang substansi dan berlakunya dan hukum tidak tertulis tumbuh dan berkembang dari bentuk kesadaran masyarakat setempat sebagai kaidah yang positif.

c. Hukum peradilan (judge made law) hukum biologis yang lahir atas dasar putusan pengadilan dan penetapan pengadilan dari lembaga peradilan. ${ }^{15}$

Eksistensi hukum Jinayah Aceh keberadaannya tidak terlepas dari keterikatan daerah Aceh dengan bangsa Indonesia. Aceh merupakan daerah yang berada di bawah naungan Indonesia yang masih berasaskan Pancasila serta bersandar pada Negara Kesatuan Republik Indonesia. Kemudian kata Eksistensi menurut KBBI (Kamus Besar Bahasa Indonesia) memiliki arti keberadaan. Sedangkan menurut kamus universal memiliki arti kecemasan masyarakat.

\footnotetext{
${ }^{13}$ Ibid Hlm 86

${ }^{14}$ Suhariyono, Kapita Selekta Sekitar Pembentukan Peraturan Perundang-Undangan, (2010), XV, Perspektif, 386.

${ }^{15}$ Zaeni Asyhadie, Arief Rahman, Ilmu Pengantar Hukum, (Jakarta: Rajawali Pers, 2016), 33-34.
} 
Eksistensi menurut Plato disusun melalui bahasa latin dari kata existere yang berartti ex adalah keluar dan sistere yang memiliki arti tampil atau muncul. Terdiri dari empat pengertian di antaranya:

1. Keberadaan merupakan ada atau apa yang ada.

2. Keberadaan merupakan aktualis

3. Keberadaan adalah sesuatu yang menekankan bahwa itu ada

4. Keberadaan merupakan kesempurnaan. ${ }^{16}$

Eksistensi secara universal ialah konsep eksistensialisme yang mengungkap eksistensi manusia sebagaimana apa yang dialami oleh masyarakat seperti kecemasan dan keresahan. Secara kontekstual eksistensi Qanun Jinayah diakui keberadaannya yang dilandasi oleh kesadaran serta kecemasan masyarakat.

Maka dari itu regulasi hukum Jinayat tidak boleh bertentangan dengan hukum pidana Nasional. Dan pada esensinya tidak ada yang bertentangan dengan hukum pidana Nasional. Walaupun tidak bertentangan, Qaun Jinayah memiliki perbedaan. Namun dari sisi perbedaan tidak menyalahi dari pada hukum Nasional.

Qanun Jinayah dalam strukturisasi Hukum Pidana Nasional telah menganut asas peraturan perundang-undangan yang menganut asas lex spesialis derogat lex generalis yang artinya bahwa Undang-Undang yang bersifat khusus mengesampingkan Undang-Undang yang bersifat umum. Dari hal ini yang mampu mengasumsikan bahwa yang membumingkan menjadi dasar bagi pemerintah Aceh untuk tetap menerapkan Qanun Jinayah yang berpegang pada Ajaran Allah yang telah termuat pada Al-Qur'an, hadist, ijma' dan qiyas.

Maka dari itu, fatwa ulama dan segenap para perancang memberlakukan Hukum Jinayah, eksistensi yang sangat kuat ialah karena Aceh diberikan otonomi khusus yang dapat ditinjau dari UU N0. 21 Tahun 2001 tentang keistimewaan Kota Aceh dan pemberlakuan Syariat Islam. Regulasi pembentukan hukum meskipun asas lex spesialis derogat lex generalis menjadi landasan substansi hukum jinayat tidak ada yang menyalahi Undang-Undang yang lebih tinggi, karena mengacu pada Undang-Undang Aceh No. 11 Tahun 2006 Tentang Pemerintahan Aceh. ${ }^{17}$

Kemudian strukturisasi memiliki dua makna yakni strukturisasi bersifat terorganisir atau disebut hirarki dengan strukturisasi dalam makna bertentangan atau tidaknya dari Qanun Jinayat dengan Hukum Pidana Nasional. Dalam hal ini dibentuknya Qanun Jinayah berdasarkan turun temurun atau hirarki yang mengacu pada Al-Qur'an, Hadist, Ijma, fatwa Ulama, Undang-Undang Dasar 1945 dan Pancasila.

\section{Implementasi Qanun Jinayat Aceh Nomor 6 Tahun 2014 dalam Perspektif Hukum Pidana Nasional}

Implementasi Qanun Jinayah Aceh No. 6 Tahun 2014. Dalam hal ini perspektif merupakan cara melihat suatu objek pada kaca mata manusia yang berdasarkan sifat atau dimensinya dan posisi mata cenderung relatif terhadap objek tersebut. ${ }^{18}$ Perspektif adalah sudut pandang atau pandangan, pandangan hukum pidana Nasional terhadap hukum Qanun Jinayat Aceh. Pandangan bersifat relatif, relatif menurut para ahli ialah kebalikan kata mutlak.

\footnotetext{
${ }^{16}$ Lorens Bagus, kamus filsafat, (Jakarta: Gramedia, 1996) hlm 183-185

17 Undang-Undang No. 11 Tahun 2006, tentang pemerintahan Aceh.

${ }^{18}$ wikipedia,Perspektif, https://id.wikipedia.org/wiki/perspektif_(visual) dikunjugi pada tanggal 21 Agustus 2020
} 
Relatif cenderung nisbi di mana sesuatu hanya dapat dinilai dan diukur apabila ada pembanding atau acuan. ${ }^{19}$

Dalam mengimplementasikan suatu bentuk peraturan tidak terlepas dari teori tujuan (Doel Theorian) teori tujuan juga disebut sebagai teri relatif (Utilitarian) yang cenderung pada si pelaku kejahatan dan tidak berdasarkan pada perbuatan pidana tersebut. Menurut Teguh Prasetyo:

Teori tujuan atau relatif merupakan usaha untuk mencegah problematik pada masa yang akan datang, dengan kata lain pidana ialah sarana dalam mencegah tindak kejahatan. Dalam hal ini terdapat 2 (dua) teori yakni teori prevensi khusus dan teori prevensi umum. Prevensi khusus ialah tindakan yang bertujuan untuk memberikan efek jera kepada pelaku agar tidak mengulangi tindakan kejahatan dan hal ini hanya ditujukan kepada pelaku. Sementara prevensi umum ialah dengan dijatuhkan sanksi pidana dengan harapan penjahat potensial dapat mengurung niatnya dan prevensi umum ditujukan kepada masyarakat pada umumnya. ${ }^{20}$

Implementasi Qanun Jinayat terhadap perspektif hukum pidana nasional muaranya terletak pada individu yang memandang. Memiliki ketegasan bahwa Qanun Jinayah Aceh dengan hukum pidana nasional memiliki perbedaan tetapi bukan pertentangan. Perbedaan tersebut terletak pada Hukum Acara. Hukum Acara merupakan hukum formal yakni hukum yang mengatur cara melaksanakan hukum serta cara menuntut apabila terdapat hak-hak seseorang dilanggar oleh orang lain. Hukum acara pada dasarnya terdapat 5 hukum acara di antaranya: Hukum Acara Perdata, Hukum Acara Peradilan Agama, Hukum Acara Pidana, Hukum Acara Peradilan Tata Usaha, Hukum Acara Mahkamah Konstitusi. ${ }^{21}$

Hukum Acara pidana merupakan keseluruhan hukum yang mengatur tentang cara melaksanakan dan mempertahankan hukum pidana materiil atau keseluruhan hukum yang mengatur tentang tindakan aparat bilamana terjadi tindak pidana atau adanya persangkaan melanggarnya Undang-Undang Pidana. ${ }^{22}$

Selain hukum acara yang menjadi perbedaan, dalam hal ini Hukum Acara Jinayah terhadap Jarimah (sanksi) pelaku tindak pidana. Perbedaan yang sangat tajam selain dari KUHAP isi dari hukum pidana itu sendiri antara Qanun Jinayah dan Hukum Pidana Nasional ialah sudut pandang yang berbeda. Perspektif relatif yakni bagaimana cara memandang memberlakukannya. Dalam segi pemberlakuan hukum terletak pada materi muatan pemberlakuan hukum tersebut.

Dalam pemberlakuan Qanun Jinayah ialah terdapat salah satu unsur yaitu unsur formal. Unsur formal dalam hukum pidana Islam merupakan peraturan yang mengatur tindakan yang dapat dinyatakan sebagai perbuatan jarimah atau adanya ketentuan-ketentuan syara' dari syariat atau nash yang menyatakan bahwa setiap perbuatan yang dilakukan merupakan perbuatan yang telah dinyatakan oleh hukum. Hal yang paling substansial dalam unsurunsur hukum ialah aturan kaidah atau aturan tingkah laku masyarakat yang diadakan oleh

\footnotetext{
${ }^{19}$ Menurut para ahli, Pengertian Mutlak dan Relatif, http://www.definisimenurutparaahli.com/pengertian-mutlakdan-relatif/ dikunjungi pada tanggal 212 Agustus 2020

${ }^{20}$ Ishaq, Hukum Pidana, (depok: Rajawali Pers, 2020), 7.

${ }^{21}$ Zaeni Asyhadie, Arief Rahman, Ilmu Pengantar Hukum, (Jakarta: Rajawali Pers, 2016), 30-31.

22 Ibid
} 
badan resmi yang bersifat mengikat dan memaksa serta ada sanksi yang tegas bagi tiap manusia yang melanggar. ${ }^{23}$

Seperti contoh jika Impelementasi Qanun Jinayat terhadap perspektif Hukum pidana Nasional muaranya terletak pada individu yang memandang. Memiliki ketegasan bahwa Qanun Jinayah Aceh dengan Hukum Pidana Nasional memiliki perbedaan tetapi bukan pertentangan. Perbedaan tersebut terletak pada Hukum Acara.

\section{Refleksi Masyarakat Terhadap Penerapan Qanun Jinayat}

Pada mulanya refleksi masyarakat terdapat dua sudut pandang yaki pro dan Kontra terhadap pemberlakuan Qanun. Dalam sudut pandang secara sosiologis masyarakat lebih menjungjung tinggi dengan adanya pemberlakuan Qanun Jinayah Ace islah masyarakat yang dominan dari kalangan Santri, para ulama, para akademisi dan praktisi hukum Islam (masyarakat yang agamis). Namun refleksi masyarakat tidak terlepas dari pengaruh budaya luar dan sudah terbiasa dengan pemberlakuan hukum pidana secara Nasional. Hal ini yang menjadi sebab banyaknya masyarakat yang kontra terhadap pemberlakuan Qanun Jinayah Aceh.

Menurut Amrunsyah S.Ag, MH selaku spesialis hukum pidana serta pengamat politik dan Qanun memberikan tanggapan mengenai refleksi masyarakat Aceh.

“ refleksi inti, para ulama-ulama, tengku dan semua kalangan santri tidak mungkin kontra terhadap pemberlakuan Qanun Aceh dan yang menolak adanya Qanun apabila ada orang yang masuk pada kawasan Aceh maka harus tunduk pada hukum Aceh, dari hal inilah yang melata belakangi adanya penolakan pemberlakuan Qanun Jinayah Aceh." 24

Beragamnya refleksi masyarakat terhadap pemberlakuan Qanun Jinayah ialah salah satunya dengan penerapan Hukuman Cambuk. Hukum cambuk dinilai dapat memunculkan kontroversi karena hukuman cambuk dianggap tidak manusiawi, dan dapat merendahkan martabat manusia. Masyarakat menyerukan kepada pemerintah untuk mengakhiri dan menghapus hukuman cambuk dalam ketentuan-ketentuan Qanun Jinayah. ${ }^{25}$

Dengan menerapkan Qanun Jinayah Aceh pemerintah perlu melakukan adanya sosialisasi kepada masyarakat agar masyarakat tidak berasumsi negatif dan sebagai penegak hukum harus tetap sesuai aturan yang berlaku dan tidak pandang bulu, dan sebagai hukum yang tertulis harus dilaksanakan sesuai aturan.

Pemberlakuan Qanun Jinayah sebagaimana untuk memengaruhi tingkah laku dan juga sebagai problem solving (penyelesaian konflik). ${ }^{26}$

Banyaknya persepsi mengenai Qanun Jinayah tidak sedikit masyarakat beranggapan bahwa Qanun Jinayah dapat melanggar HAM (Hak Asasi Manusia). Tentang HAM pasti menentang dengan adanya pemberlakuan Qanun Jinayah yang mampu mempengaruhi pola pikir masyarakat. Pemberlakuan Qanun Jinayah secara inti tidak menentang dan tidak melanggar HAM. Apabila melihat Qanun Jinayah dari kacamata HAM kebarat-baratan tentu adanya pelanggaran namun secara perspektif HAM Islam pemberlakuan Qanun Jinayah tidak

\footnotetext{
${ }^{23}$ Mustofa hasan, Beni Ahmad Saebani, Hukum Pidana Islam Figh Jinayah, (Bandung: Pustaka Setia, 2013) hlm 170

${ }^{24}$ Hasil wawancara dengan Amrunsyah S.Ag, MH selaku tokoh yangjuga terlibat dalam pembentukan Qanun Aceh, tanggal 15 A gustus 2020, di kota Aceh

${ }^{25}$ Anifah, edi sukardi, tanggapn masyarakat terhadap penerapan hukuman cambuk di daerah singkil kabupaten Aceh singkil, (2019), vol 3, jurnal Sekolah, hlm 197

${ }^{26}$ Ishaq, Hukum Pidana, (Depok: Rajawali Pers, 2020), 4.
} 
menimbulkan perdebatan. Hal ini sesuai dengan vegeldings theorieen yang menyatakan bahwa kejahatan yang membuat anasir-anasir yang menuntut adanya pidana untuk dijatuhkan. Pidana dijatuhkan karena adanya pelanggaran hukum. Dalam pandangan retributive dapat dijatuhkan pidana apabila orang telah melakukan kejahatan. Sehubungan dengan konsep pembalasan tokoh J.E Sahetapy mengungkapkan bahwa kecenderungan untuk membalas ialah suatu gejala yang normal namun, manusia bukanlah hewan karena masih memiliki akal dan perasaan. Tiap manusia yang melakukan kejahatan harus dijatuhkan pidana karena pidana merupakan hal mutlak dan keharusan hakikat adanya suatu pidana ialah pembalasan. ${ }^{27}$

Dalam pemberlakuan Qanun Jinayah tidak dapat melanggar HAM karena hal ini merupakan bentuk pertanggungjawaban pidana dalam rancangan Undang-Undang Hukum Pidana Tahun 2013. Dalam Rancangan Undang-Undang Republik Indonesia tentang Kitab Undang-Undang Hukum Pidana Tahun 2013 dalam pasal 36 menegaskan bahwa “ Pertanggungjawaban pidana adalah diteruskannya celaan yang bersifat objektif pada tindak pidana dan celaan yang bersifat subjektif kepada orang yang memenuhi syarat untuk dijatuhi pidana karena perbuatannya". ${ }^{28}$

Eksekusi hukum yang dapat menyita perhatian masyarakat Aceh ialah Hukuman Cambuk. Hukuman cambuk diartikan beragam oleh masyarakat Aceh, beragamnya persepsi masyarakat dipengaruhi oleh beberapa hal di antaranya, minimnya pengetahuan dan edukasi masyarakat terhadap pelaksanaan hukum syari'at Islam, implementasi Qanun Jinayah terhadap hukuman cambuk, hal yang dapa memicu miringnya persepsi hukuman cambuk ialah cara manusia dalam mencari pengetahuan, mengolah berdasarkan pengetahuan yang didapat. ${ }^{29}$

Dengan beragamnya faktor yang menjadi pemicu ragamnya persepsi ialah pentingnya sosialisasi kepada masyarakat yang dilakukan secara berkelanjutan. Dalam menerapkan Qanun Jinayah perlu peran dari semua pihak salah satunya yang berperan penting ialah peran keluarga. Peran yang menjadi tonggak utama untuk memberikan edukasi mengenai syariat Islam agar tidak menjadi pribadi yang melanggar Syariat Islam. Selain peran keluarga yaitu lingkungan. Lingkungan menjadi faktor melakukan sistem Controlling terhadap individu mampu menetralisasi adanya pelanggaran norma. Adanya hubungan antar individu mampu menjadi pemicu dalam menentukan tingkah laku manusia. Hal yang perlu diperhatikan ialah:

1. Memberikan pengetahuan dan edukasi secara komprehensif kepada semua lapisan masyarakat terkait tentang Syariat Islam dan Qanun Jinayah

2. Mengatur mekanisme hukuman.

3. Melakukan proses perbaikan psikologis pada terdakwa atau pelanggar.

4. Peran keluarga dan lingkungan yang perlu diperhatikan untuk meminimalisir pelanggaran norma syari'at Islam. ${ }^{30}$

Maka dari itu, hukum selalu melekat pada sendi-sendi manusia, sebagai makhluk individu maupun sosial. Pemberlakuan hukum Qanun Jinayah sebagai sarana penggerak serta penyelesaian permasalahan secara syariat Islam. Guna untuk mewujudkan

\footnotetext{
27 Ibid., 5-6.

28 Ibid., 94-95.

${ }^{29}$ Nurbaiti, Wahyuni, Makbbul Rizki, Hayyun Nisa, "Pandangan Masyarakat Terhadap Pelaksanaan Hukuman Cambuk", (2019) Indeginious: Jurnal Ilmiah Psikologi, 4, 98.

30 Ibid., 103
} 
ketenteraman sosial serta sebagai pemersatu bangsa untuk meningkatkan stabilitas kewibawaan.

\section{Kesimpulan}

Qanun Jinayah merupakan hukum yang berlaku bagi masyarakat Aceh, dengan mengedepankan syariat Islam. Karena Aceh memiliki otonomi khusus untuk memberlakukan Hukum Islam. Perlu diketahui bahwa pidana dan hukuman memiliki sisi perbedaan. Letak perbedaannya apabila pidana telah tercantum pada nash-nash yang legal dan formal atau terdapat pada ketentuan-ketentuan Undang-Undang sedangkan hukuman cakupan pengertiannya sangat luas yang semuanya didasari oleh kesopanan, kesusilaan, kepatutan serta kebiasaan. Qanun Aceh juga diakui eksistensi atau keberadaannya dalam strukturalisasi hukum pidana Nasional. Adanya Qanun Jinayah didasari atas landasan Filosofis, sosiologis, yuridis hingga historis. Qaun Jinayah dalam strukturisasi Hukum pidana Nasional menganut Asas lex spessialis derogat lex generalis terbentuknya Qanun Jinayah berdasarkan Al-Qur'an, sunnah, ijma' Qiyas, serta Undang-Undang yang lebih tinggi. Implementasi Qanun Jinayat terhadap perspektif Hukum pidana Nasional muaranya terletak pada individu yang memandang. Memiliki ketegasan bahwa Qanun Jinayah Aceh dengan Hukum Pidana Nasional memiliki perbedaan tetapi bukan pertentangan. Perbedaan tersebut terletak pada Hukum Acara. Implementasi Qanun Jinayat terhadap perspektif Hukum pidana Nasional muaranya terletak pada individu yang memandang. Memiliki ketegasan bahwa Qanun Jinayah Aceh dengan Hukum Pidana Nasional memiliki perbedaan tetapi bukan pertentangan. Perbedaan tersebut terletak pada Hukum Acara. Namun pemberlakuan Qanun Jinayah tidak terlepas dari pandangan masyarakat yang relatif kontra maupun pro terhadap penerapan Qanun Jinayah. Edukasi mengenai Syariat Islam dan Qanun Jinayah harus dilakukan secara berkelanjutan. Mengatur mekanisme hukuman harus diterapkan guna untuk meminimalisir psikologi miring terhadap adanya Qanun Jinayah salah satunya ialah Hukum Cambuk, melakukan proses perbaikan psikologi terhadap para pelanggar serta peran yang efektif bagi keluarga serta lingkungan untuk meminimalisir tingkat pelanggaran norma. Hukum selalu melekat pada kehidupan manusia, hukum diakui eksistensinya dengan berdasarkan Undang-Undang yang telah legal. Hasil output dengan adanya Qanun Jinayah ialah mampu memberikan Undang-Undang yang baru.

\section{Daftar Pustaka}

\section{Buku}

Bagus, Lorens. 1996. Kamus Filsafat. Jakarta: Gramedia

Ishaq. 2020. Hukum Pidana. Depok: Rajawali Pers

Marzuki, Peter Mahmud. 2016. Penelitian Hukum. Jakarta: Pt Kharisma Putra Utama

Moeleong, Lexy J. 2010. Metodologi Penelitian Kualitatif. Bandung: Remaja Rodakarya

Mustofa hasan, beni ahmad saebani. 2013. Hukum Pidana Islam Figh Jinayah. Bandung: Pustaka Setia

Suhariyono. 2010. Kapita Selekta Sekitaar Pembentukan Peraturan Perundang-Undangan, (2010), $\mathrm{XV}$, Perspektif.

Suharsimi, Arikunto. 2002. Metodoloogi Penelitian. Jakarta: PT Rineka Cipta

Zaeni Asyhadie, Arief Rahman. 2016. Ilmu pengantar Hukum. Depok: Rajawali Pers 


\section{Jurnal}

Anifah, edi sukardi. 2019. “Tanggapn Masyarakat Terhadap Penerapan Hukuman Cambuk Di Daerah Singkil Kabupaten Aceh Singkil", vol 3, jurnal Sekolah

Nurbaiti, wahyuni, makbbul rizki, hayyun nisa. 2019. "Pandangan Masyarakat Terhadap Pelaksanaan Hukuman Cambuk" Indeginious: Jurnal Ilmiah Psikologi

\section{Laman Website:}

http://fsyariah.iain-jember.ac.id/berita/detail/efektivitas-qanun-jinayah-dalam-strukturisasihukum-pidana-Nasional- dikunjungi pada tanggal 16-08-2020

http://www.definisimenurutparaahli.com/pengertian-mutlak-dan-relatif/

https://id.wikipedia.org/wiki/perspektif_(visual)

\section{Perundang-undangan}

Undang-Undang No. 11 Tahun 2006, tentang pemerintahan Aceh. 